\title{
Are bone losers distinguishable from bone formers in a skeletal series? Implications for adult age at death assessment methods
}

\author{
A. Schmitt ${ }^{\mathrm{a}, *}$, U. Wapler ${ }^{\mathrm{a}}$, V. Couallier ${ }^{\mathrm{b}}$, E. Cunha ${ }^{\mathrm{c}}$ \\ ${ }^{a}$ PACEA - Laboratoire d'Anthropologie des Populations du Passé. UMR 5199, Université \\ Bordeaux 1, Talence, France \\ ${ }^{\mathrm{b}}$ Equipe Statistique Mathématique et ses Applications, Université Bordeaux 2, Bordeaux, France \\ ${ }^{\mathrm{c}}$ Departamento de Antropologia, Universidade de Coimbra, Coimbra, Portugal
}

Received 21 February 2006; accepted 25 August 2006

\begin{abstract}
Clinical studies indicate that genetic factors play a crucial role in primary osteoarthritis and osteoporosis. In addition, it has been suggested that these two diseases are inversely related. Within a population, one can find two sub-groups: the "bone formers" and the "bone losers". The changes to the joint surfaces used to assess adult age at death are related to the loss of bone substance and to bone formation (osteophytes). The modification of these indicators with age differs between bone formers and bone losers. Therefore, age-at-death assessment methods should make use of two standards, one for each sub-group. A preliminary study examining the possibility of distinguishing those who lose cortical bone from those who show signs of bony formation was conducted on a series of skeletons from Portugal, dating to the end of 19 th century and the beginning of the 20th. Bone loss was evaluated using the cortical index (CI) of the second metacarpal on X-rays. The presence of osteophytes on dry bones was assessed macroscopically.

Our study indicates that females' CI decreases with age, whereas the presence of osteophytes is strongly related to age in both sexes. But we have failed to find the inverse relationship
\end{abstract}

\footnotetext{
*Corresponding author. Tel.: + 33540002539 .

E-mail address: schmitt.aurore@wanadoo.fr (A. Schmitt).
} 
between osteophytes and bone loss. Our study, however, shows that within a population, some individuals are not likely to develop osteophytes.

(C) 2007 Elsevier GmbH. All rights reserved.

\section{Résumé}

De nombreuses études démontrent que les facteurs génétiques jouent un rôle crucial dans le développement de l'arthrose et de l'ostéoporose et que ces deux maladies sont inversement proportionnelles. En effet, au sein d'une même population, deux groupes se distinguent: les «bone fomers» (ceux qui fabriquent de la substance osseuse) et les «bone losers» (ceux qui ont tendance à la perdre). Or, les modifications des surfaces articulaires utilisées pour estimer l'âge au décès des adultes sont liées à la formation et à la perte de substance osseuse. Par conséquent, ces indicateurs évoluent différemment selon la catégorie à laquelle l'individu appartient. Chaque méthode devrait donc proposer deux standards différents. Pour tester cette hypothèse, une étude préliminaire a été menée sur une série de squelettes portugais (fin du $19^{\text {ième }} /$ début du $20^{\text {ième }}$ siècle). Son objectif est de savoir s'il est possible de distinguer les «bone formers» des «bone losers». La perte osseuse a été évaluée par l'index cortical du second métacarpien sur radiographies. La présence d'ostéophytes a été diagnostiquée sur os sec. La relation inverse entre les ostéophytes et la perte osseuse n'a pas été démontrée. Par conséquent, la tentative de distinguer les «bone losers» et les «bone formers» s'est révélée infructueuse. Toutefois, notre étude indique que certains individus ne développent pas d'ostéophytes.

(C) 2007 Elsevier GmbH. All rights reserved.

\section{Introduction}

Assessing the age at death of adult skeletons is one of the most difficult problems in forensic and physical anthropology. Age-related processes show great variation in expression and degree of change with increasing age, both within and among populations (Harper and Crews, 2000; Schmitt, 2002). The relationship between chronological age and skeletal age indicators is neither constant nor linear. Therefore, adult ages at death cannot be estimated with accuracy from skeletal data (Cox, 2000).

Most morphological methods are elaborated on joint surfaces such as the auricular surface of the ilium. The technique proposed by Lovejoy et al. (1985) to assess age at death from this indicator was recently revised by several researchers (Boldsen et al., 2002; Buckberry and Chamberlain, 2002; Igarashi et al., 2005; Schmitt, 2005). These studies indicate a large variability between individuals in morphological changes with ageing. Such results were expected since the modification with age of this joint surface is related to loss of bone substance and bone formation. Degeneration of the cartilage, inducing the formation of osteophytes defines primary osteoarthritis, while reduced bone mass inducing an increased risk of fragility fractures characterizes osteoporosis. Both diseases appear with increasing age in all human populations. They are related to various factors (ageing, genetic, hormonal and lifestyle) that are major contributors to their onset and progression. However, there is strong evidence that genetic factors play a crucial role in the 
degeneration of bone and cartilage (Bateman, 2005; Livshits, 2005; Loughlin, 2005; Ralston, 2005; Spector and MacGregor, 2004).

Over the last several decades, the inverse association between osteoarthritis and osteoporosis has been demonstrated in many clinical studies (Belmonte-Serrano et al., 1993; Bettica et al., 2002; Bischoff et al., 2000; Burger et al., 1996; Del Puente et al., 2003; Dequeker et al., 2003; El Miedany et al., 2000; Hochberg et al., 2004; Iwamoto et al., 2002; Marcelli et al., 1995; Naganathan et al., 2002; Nevitt et al., 1995; Sowers et al., 1999; Yahata et al., 2002). Individuals with clinical and radiographic osteoarthritis present higher adjusted levels of bone mass than those without osteoarthritis. Alterations in the bone in patients with osteoarthritis lead to increased bone formation and protect against bone loss. These patients are known as "bone formers" (Crubézy et al., 2002; Greenfield and Goldberg, 1997) and the others as "bone losers".

These findings bring new insight into methods for assessing the age at death of adults. If osteoarthritis and osteoporosis are inversely associated, then a skeletal series should be divided into bone losers and bone formers. As the morphological modifications of joint surfaces with age do not follow the same pattern in each category, any methods based on bone loss and bone formation should make use of two standards.

The first step consists of verifying whether the identification of bone formers and bone losers is possible in a skeletal series.

In the present paper, the association between shoulder, elbow, wrist, hand, spine, hip, knee, ankle and foot osteophytes and bone loss, is analysed in a skeletal series from a cemetery in Coimbra, Portugal. The analysis takes sex and age into account.

\section{Materials}

Our skeletal sample was chosen from the large Identified Skeletal Collection of the Museum of Anthropology, and consisted of 505 skeletons of individuals identified as Portuguese (Rocha, 1995). The individuals died between 1910 and 1936. In order for a specimen to be selected, several criteria had to be met. Skeletons affected by tuberculosis, cancer and rheumatoid diseases were excluded. This exclusion applied not only to obvious and declared pathological cases but also to questionable cases. Specimens affected by osteoarthritis related to fractures were also excluded. Other criteria were bone preservation and a homogeneous age-at-death distribution. One hundred and thirty specimens (65 females, 65 males) were available. Age at death ranged from 21 to 89 years, with a mean age of $49.8, \mathrm{SD}=17.75$ (Fig. 1).

\section{Methods}

Among the signs of osteoarthritis, only marginal osteophytes, due to the ossification of joint capsules and ligaments, are signs of overall bone formation. 


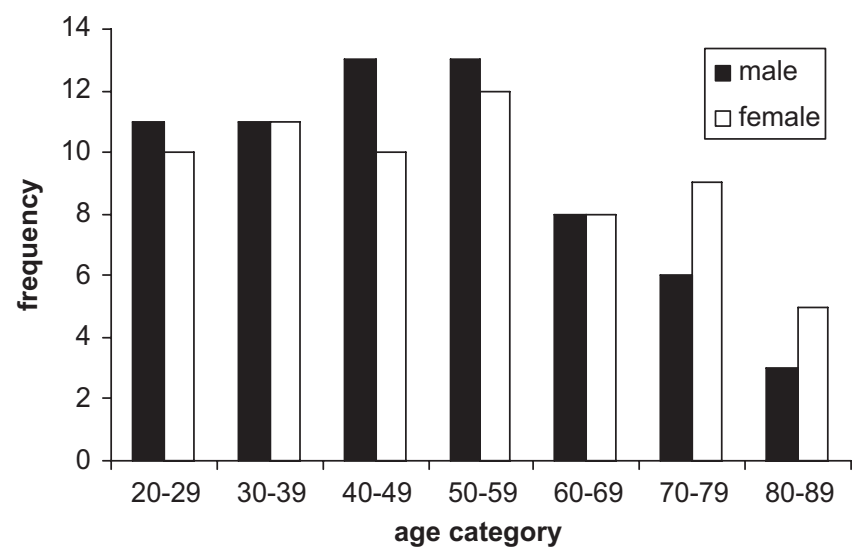

Fig. 1. Distribution of age at death in years of the skeletal sample.

Some authors consider osteophytes as characteristic of osteoarthritis (Crubézy et al., 2002; Resnick and Niwayama, 1988). Following the latter, in the present study we have used osteophytes as the identifier of osteoarthritis. The presence of osteophytes was marked as grade 1 and their absence was marked as grade 0 . In each skeleton, each joint was observed (shoulders, elbows, hands, wrists, spine, hips, knees and feet).

Dual-energy X-ray absorptiometry (DXA) or bone density scanning is largely used to study bone loss on living individuals, but in archaeological skeletons the densiometric readings may be biased by alterations in bone density during diagenesis (Bell and Jones, 1991; Mays et al., 1998). Thus, it is equally appropriate to assess bone loss in osteological series by radiogrammetry. This technique consists of measuring the thickness of cortical bone on radiographs in the second metacarpal. Radiogrammetry remains an important research tool in epidemiological studies on living populations (e.g. Crespo et al., 1998; Kalichman et al., 2002, 2005; Maggio et al., 1997; Montalban Sanchez et al., 2001; Haara et al., 2006), but recently, it has also been used in studies of cortical bone loss in archaeological human remains to assess the probable prevalence of osteoporosis in the past (Mays, 2000, 2001, 2006). $\mathrm{X}$-ray equipment is available to most osteologists (Mays, 1996); thus, this method is also more convenient to use in osteological research.

Only perfectly intact bones without soil erosion were selected. Antero-posterior radiographs were made of the left metacarpal. Either left or right is suitable for use (Ives and Brickley, 2004).

Radiographs were taken using mammogram film (Agfa Curix Blue) with an exposure time of $10 \mathrm{~s}$ at $6.4 \mathrm{~mA}$. An exposure of $45 \mathrm{kV}$ was used. Cortical thickness measurement was obtained using the cortical index (CI):

$$
\mathrm{CI}=\frac{\text { total bone width }- \text { medullary width }}{\text { total bone width }} \times 100 .
$$


Each radiograph was scanned at its true size. Measurements were taken at the midshaft using Adobe Illustrator.

Statistical analyses were carried out using SPSS for Windows version 9.0.1. Simple linear regression was used to examine the correlation between CI and age for the two sub-samples determined by the sex. As individuals lose bone after reaching middle age (Mays, 2000, 2001), the regression analyses were done on individuals over 40 years old.

Comparison of mean values of age and of CI by grade of hand, hip, knee and spine was performed using one-way analysis of variance (ANOVA). In order to evaluate the real effects of osteophytes, it was necessary to take into account the confusion of these effects with those of ageing in the modelling of CI. Therefore, an analysis of covariance was used. This is a generalization of both classical regression and one-way ANOVA and it relies on the General Linear Modelling approach (McCullagh and Nelder, 1989; Scheffé, 1959). In order to test the effect of a factor (such as osteophytes presence) on the mean value of a dependent variable (such as $\mathrm{CI})$, it is theoretically justified to embed a current model (CI intercept + age) in a wider model that includes this factor as an extra covariate $(\mathrm{CI} \sim$ intercept + age + osteophytes). The analysis of covariance is the correct way to test these nested models. In our case the aim was to test the relationship between CI and osteophytes by taking into account the effect of ageing.

\section{Results}

Correlation between the CI and age was significant in both sexes $(p<0.001)$. However, the correlation coefficient in females $(r=0.7259)$ was higher than that in males $(r=0.083)$. The CI tended to diminish with age in females but not in males (Fig. 2). Thirty-nine women (60\%) and thirty-eight men (58\%) had at least one joint affected by osteophytes. The number of affected sites in each individual varied between 0 and 11 for both sexes. The median value was 1 .

Mean values with standard deviations for age and cortical index by presence of osteophytes are shown in Table 1. The mean values of age were statistically significantly different by grade of osteophytes for all joints in both sexes.

Women with knee and spine osteophytes presented a lower CI than those without osteophytes. It is likely that the relation observed between the CI and the osteophytes is actually an effect of age. Therefore, we used the explanatory covariates, age and osteophytes both in the same model, as far as the women were concerned.

The analysis of covariance is an ordinary least-squares estimation in the general linear model with age and a dummy variable (with value 0 when the subject does not present osteoarthritis and with value 1 when osteoarthritis is present) as regressor. The results in Table 2 show that in females only age is related to CI. For instance, the model $\mathrm{CI} \sim$ age + knee osteophytes gives the estimated formula: $\mathrm{CI}=74.188-$ 0.371 *age for women with knee osteophytes and $\mathrm{CI}=70.685-0.371$ *age -1.356 for women without knee osteophytes. The difference is the estimated parameter of the 

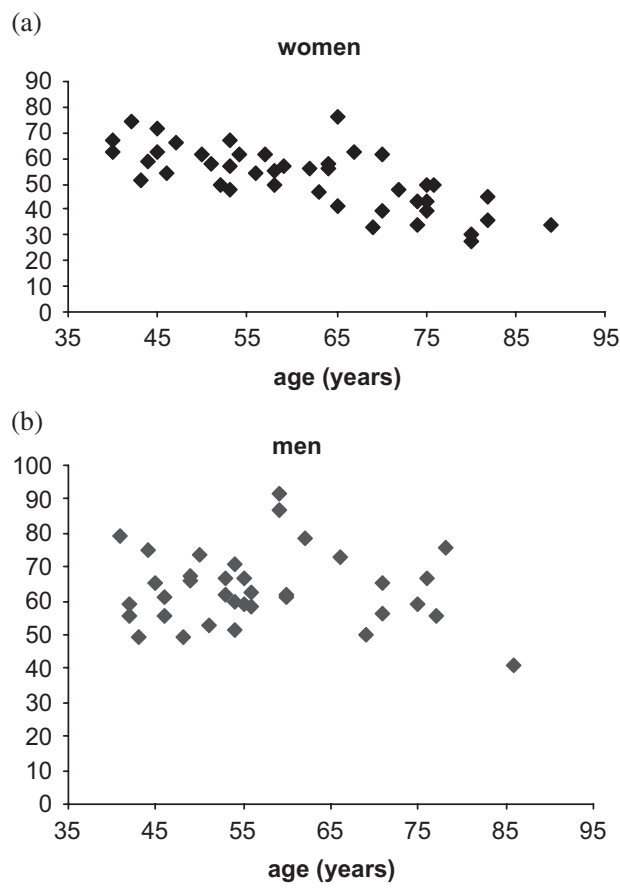

Fig. 2. Distribution of cortical index by age for men (a) and women (b).

osteophytes factor in this model. This difference is not statistically significant $(p=0.671)$. Both regression lines may be considered as equivalent. The relationship between $\mathrm{CI}$ and knee osteophytes in women is not causative but related to age. The same kind of result was obtained for spine osteophytes (Table 3).

Therefore, bone formers are not distinguishable from bone losers in our skeletal sample, as the inverse relationship between osteophytes and bone loss is not demonstrated.

\section{Discussion}

The loss of bone density, especially in post-menopausal women, is documented by many researchers (Burger et al., 1996; Hannan et al., 1993; Iwamoto et al., 2002; Jones et al., 1995; Nuti and Martini, 1993; Peterlik, 1997; Schneider et al., 2002). The deficiency of oestrogen observed with ageing is an important factor in the pathogenesis of bone fragility (Currey, 1969). The oestrogen withdrawal increases the rate of bone remodelling. As more bone is resorbed than replaced, it induces bone loss (Nordin and Polley, 1987). This pattern is observed not only in contemporary populations but also in the skeletal sample from the Identified Spitalfields Collection from 18th and 19th century (Mays, 2000, 2001). Extensive 
Table 1. Distribution of cortical index and age by grade of osteophytes for shoulder, elbow, wrist, hand, hip, knee, ankle and foot

\begin{tabular}{|c|c|c|c|c|c|c|}
\hline \multirow[t]{2}{*}{ Shoulder } & \multicolumn{3}{|l|}{ Female } & \multicolumn{3}{|l|}{ Male } \\
\hline & Cortical index & Age & $N$ & Cortical index & Age & $N$ \\
\hline Absent & $55.5 \pm 11.2$ & $42.1 \pm 16.6$ & 35 & $64.1 \pm 10.5$ & $36.3 \pm 11.5$ & 27 \\
\hline Present & $53.1 \pm 11.9$ & $62.12 \pm 14.3$ & 29 & $63.3 \pm 10.8$ & $57.69 \pm 13.5$ & 29 \\
\hline$p$-value & 0.383 & $<0.001$ & & 0.767 & $<0.001$ & \\
\hline \multicolumn{7}{|l|}{ Elbow } \\
\hline Absent & $55.9 \pm 10.7$ & $45.1 \pm 16.1$ & 45 & $63.6 \pm 10.5$ & $43.3 \pm 14.9$ & 40 \\
\hline Present & $50.8 \pm 12.8$ & $65.58 \pm 15.8$ & 19 & $64.5 \pm 12.1$ & $56.27 \pm 15.9$ & 15 \\
\hline$p$-value & 0.107 & $<0.001$ & & 0.801 & 0.007 & \\
\hline \multicolumn{7}{|l|}{ Wrist } \\
\hline Absent & $54.5 \pm 10.6$ & $47.5 \pm 18.4$ & 48 & $64.5 \pm 10.7$ & $46 \pm 16.3$ & 51 \\
\hline Present & $54.4 \pm 14.2$ & $62.19 \pm 14.2$ & 16 & $55.7 \pm 5$ & $61.6 \pm 10.8$ & 5 \\
\hline$p$-value & 0.997 & 0.005 & & 0.075 & 0.042 & \\
\hline \multicolumn{7}{|l|}{ Hand } \\
\hline Absent & $55.2 \pm 12.1$ & $47.3 \pm 18.8$ & 47 & $63.9 \pm 11.2$ & $43.03+/ 16.8$ & 39 \\
\hline Present & $52.2 \pm 9.5$ & $61.9 \pm 12.6$ & 17 & $63.2 \pm 9.2$ & $57.4 \pm 10.4$ & 17 \\
\hline$p$-value & 0.365 & 0.004 & & 0.833 & 0.002 & \\
\hline \multicolumn{7}{|l|}{ Hip } \\
\hline Absent & $57.3 \pm 8.2$ & $38.2 \pm 13.9$ & 26 & $63.4 \pm 10.6$ & $37.4 \pm 11.6$ & 25 \\
\hline Present & $52.4 \pm 13$ & $60.1 \pm 15.9$ & 38 & $63.9 \pm 10.8$ & $55.4 \pm 15.5$ & 31 \\
\hline$p$-value & 0.099 & $<0.001$ & & 0.859 & $<0.001$ & \\
\hline \multicolumn{7}{|l|}{ Knee } \\
\hline Absent & $58.3 \pm 8.7$ & $39.1 \pm 14$ & 32 & $63.1 \pm 9$ & $40 \pm 13.8$ & 32 \\
\hline Present & $50.9 \pm 12.6$ & $62.7 \pm 13.8$ & 31 & $64.6 \pm 12.6$ & $58 \pm 14.2$ & 31 \\
\hline$p$-value & 0.009 & $<0.001$ & & 0.617 & $<0.001$ & \\
\hline \multicolumn{7}{|l|}{ Ankle } \\
\hline Absent & $55.5 \pm 10.1$ & $45.77 \pm 17.3$ & 43 & $63.7 \pm 10.5$ & $44.49 \pm 14.2$ & 43 \\
\hline Present & $52.3 \pm 14.2$ & $62.1 \pm 16.5$ & 19 & $64 \pm 11.5$ & $55.5 \pm 20.3$ & 19 \\
\hline$p$-value & 0.313 & 0.001 & & 0.94 & 0.036 & \\
\hline \multicolumn{7}{|l|}{ Foot } \\
\hline Absent & $54.1 \pm 11.4$ & $49.8 \pm 19.1$ & 54 & $64 \pm 10.6$ & $44.8 \pm 15.3$ & 49 \\
\hline Present & $57.2 \pm 10.9$ & $58.4 \pm 8.4$ & 8 & $61.5 \pm 10.8$ & $65 \pm 14.9$ & 7 \\
\hline$p$-value & 0.475 & 0.217 & & 0.562 & 0.002 & \\
\hline \multicolumn{7}{|l|}{ Spine } \\
\hline Absent & $58.88 \pm 10.2$ & $36.9 \pm 11.5$ & 30 & $66.3 \pm 8.6$ & $35.5 \pm 11$ & 19 \\
\hline Present & $50.4 \pm 11.3$ & $63.8 \pm 13.7$ & 34 & $62.6 \pm 11.6$ & $54.1 \pm 14.3$ & 35 \\
\hline$p$-value & 0.003 & $<0.001$ & & 0.24 & $<0.001$ & \\
\hline
\end{tabular}

Standard deviations are given after the \pm sign. 
Table 2. ANCOVA analyses of cortical index with age and knee osteophytes as covariates for females

\begin{tabular}{lclrr}
\hline Parameter & $B$ & Standard error & $t$ & Significance \\
\hline Constant & 74.188 & 5.775 & 12.846 & $<0.001$ \\
Age & -0.371 & 0.088 & -4.213 & $<0.001$ \\
Knee O: 0 & -1.356 & 3.179 & -0.427 & 0.671 \\
Knee O: 1 & $0^{\mathrm{a}}$ & & & \\
\hline
\end{tabular}

$B$ : Estimated values of regression coefficients.

$t$ : Student statistic for testing the null hypothesis.

O: Osteophytes.

${ }^{\text {a }}$ This parameter is 0 because it is redundant.

Table 3. ANCOVA analyses of cortical index with age and spine osteophytes as covariates for females

\begin{tabular}{llllr}
\hline Parameter & $B$ & Standard error & $t$ & Significance \\
\hline Constant & 76.534 & 6.264 & 12.218 & $<0.001$ \\
Age & -0.409 & 0.095 & -4.312 & $<0.001$ \\
Spine O: 0 & -2.551 & 3.486 & -0.732 & 0.467 \\
Spine O: 1 & $0^{\mathrm{a}}$ & & & \\
\hline
\end{tabular}

$B$ : Estimated values of regression coefficients.

$t$ : Student statistic for testing the null hypothesis.

O: Osteophytes.

${ }^{\mathrm{a}}$ This parameter is 0 because it is redundant.

data on metacarpal changes in various populations show bone loss with ageing in both sexes (Falch and Sandvik, 1990; Geusens et al., 1986; Maggio et al., 1997). In our study, the association between CI and age is statistically significant in both sexes, but much greater in women than in men. Men over 60 years old (Fig. 2b) show no wider medullary cavities than younger individuals. There is a great interindividual variation in the rate of resorption from the endosteal surface. The primary causes of age-related bone loss in men are complex and not completely understood (Halloran and Bikle, 1999). In men, there is no midlife increase in bone remodelling. Besides, men start with a larger skeleton at the peak of physical development and trabecular bone loss proceeds with less architectural disruption (Seeman, 2004).

In both sexes we observe a strong correlation between age and the presence of osteophytes, whatever joint is involved. In our sample, osteophytes were present in 77 cases in individuals 27-89 years old. But it is relevant to note that osteophytes were absent in 53 individuals between 21 and 54 years of age. We do not reject the hypothesis that some of these individuals would have developed osteoarthritis if they had lived longer. However, this distribution may indicate that within a population some individuals are bone formers and others are not. The reasons for cartilage degeneration and bone formation are still poorly understood (Ortner, 2003). Risk 
factors are numerous and varied (Sowers, 2001). Pathogenesis of osteoarthritis involves complex interactions between anatomy, physiology, biochemistry and the biomechanical function of the joint (Falchetti, 2002; Resnick and Niwayama, 1988). There is a general consensus that joint use is an important factor. But there may be also a genetic predisposition expressed through metabolic and endocrine factors that increase the probability of osteoarthritis occurring (Solomon, 2001). Some individuals may have increased potential to form bone (Rogers and Waldron, 1995).

The relationship between cortical bone loss measured on the second metacarpal and osteophytes on the skeleton joints was tested. In both sexes, individuals with osteophytes had a similar age-adjusted CI to those without osteophytes. It would be surprising that our study failed to confirm the association between osteoarthritis and bone loss only because the individuals in our sample lived at the end of the 19th to the beginning of the 20th century. It seems very unlikely that the fundamentals of bone physiology have changed in such short time, in a manner that would separate our population from the present (Brickley and Waldron, 1998).

The techniques used to diagnose osteophytes and bone loss on dry bones might not be appropriate for this study. But in most clinical studies, osteoarthritis is diagnosed by the Kellgren and Lawrence (1957) radiological criteria which take into account the presence of osteophytes. Bone mass assessed on the radiographs of the second metacarpal is more likely to explain our negative results. Considering this particular point, our study is comparable only with the study of Kalichman et al. (2002). These authors used CI and roentgenographic densitometry of hand bones to assess bone loss. After adjustment for age, correlation between hand osteoarthritis and traits of osteoporosis (CI and densitometry of the hand) became very low and insignificant in both sexes.

One may argue that $\mathrm{CI}$ is not an appropriate technique to diagnose bone loss because cortical bone is later and to a lesser degree affected by osteoporosis. The physiological turnover in cortical bone is much slower and less severe than in cancellous bone (Ortner, 2003). But radiogrammetry on the second metacarpal is proved to be a relevant diagnostic tool in osteoporosis (Boonen et al., 2005; Crespo et al., 1998; Haara et al., 2006) and loss of cortical bone plays an important role in increasing bone fragility (Boyce and Bloebaum, 1993). Besides, some studies using DXA (Drees et al., 2005a, b; Hochberg et al., 1991, 1994, 1995, 2004; Hulet et al., 2002; Kalichman et al., 2002; Ohtsuka et al., 2002; Schneider et al., 2002) could not confirm the inverse relationship between osteoarthritis and osteoporosis.

According to the review of Dequeker et al. (2003), 43 studies published between 1972 and 2002 show associations between higher mean levels of bone mineral density measured at the lumbar spine and/or hip and the presence of radiographic osteoarthritis at multiple sites including hand, hip, knee and lumbar spine. Only 10 studies reported no increase in bone density associated with osteoarthritis. However, it is difficult to compare these studies which analyse the association between osteoarthritis and high bone mass density. Sample selection, technical methods and anatomical sites for osteoarthritis and bone mineral density diagnosis vary greatly between studies. 
A few studies present a large age range (Hochberg et al., 1991, 1994, 2004) but many are limited to post-menopausal women (Bettica et al., 2002; Iwamoto et al., 2002; Schneider et al., 2002; Yahata et al., 2002; Del Puente et al., 2003) or elderly people (Marcelli et al., 1995; Nevitt et al., 1995; Burger et al., 1996). Generally, the samples were not randomized in the majority of the studies. For some investigations, the subjects were selected because they showed severe osteoarthritis (Hulet et al., 2002). In other studies, the sample was constituted of volunteers (Hochberg et al., 1991, 1994, 1995, 2004) or was selected from a geriatric hospital (Bischoff et al., 2000). The number of individuals varied from 40 to thousands.

Generally osteoarthritis is radiographically diagnosed according to the Kellgren and Lawrence (1957) system. However, in a few studies the diagnosis of osteoarthritis has been based on a clinical physical examination (Bischoff et al., 2000; Schneider et al., 2002) which may furnish different results than radiological diagnosis. Hand radiographs may lead to the overdiagnosis of osteoarthritis since many individuals are considered affected, although they do not suffer from symptoms (Schneider et al., 2002).

The majority of the studies used DXA to determine bone mineral density, but other methods were also used, such as quantitative ultrasound measurement (Belmonte-Serrano et al., 1993; Bischoff et al., 2000; Naganathan et al., 2002) and metacarpal percentage of cortical area (Hochberg et al., 1991, 1994, 1995; Yahata et al., 2002).

The anatomical site of bone mass measurements varies between the studies. It is often measured on bones located near weight-bearing joints, such as femur, lumbar spine or knee (e.g. Sowers et al., 1999; Schneider et al., 2002; Marcelli et al., 1995; Burger et al., 1996; El Miedany et al., 2000; Del Puente et al., 2003). However, many studies proposed to measure bone mineral density in a peripheral bone site such as radius, metacarpal or phalanges (e.g. Hochberg et al., 1991, 1994, 1995; Bischoff et al., 2000; Iwamoto et al., 2002; Yahata et al., 2002; Ohtsuka et al., 2002). Furthermore, the distance between osteoarthritis sites and sites of bone mineral density measurements varied between the studies.

In reality, the mechanisms behind the relationship between osteoarthritis and osteoporosis may be more complex than previously suggested. Studies on this topic are rather complex because bone mass and osteoarthritis share common confounders such as weight, several lifestyle risk factors and physical activity (Naganathan et al., 2002) which may induce an indirect relationship. Moreover, the phenotype of bone fragility and osteoarthrosis is poorly defined (Falchetti, 2002; Seeman, 2003).

Osteoarthritis and increased bone loss may develop independently in an individual (Kalichman et al., 2002) and, it is well recognized that bone loss and osteoarthritis are both common in elderly patients (Cooper et al., 1991; Dequeker, 1997; Sandini et al., 2005; Sowers et al., 1991). Indeed, in several studies (Hochberg et al., 2004; Iwamoto et al., 2002; Hulet et al., 2002; Schneider et al., 2002), patients with low bone density also had osteoarthritis. Dequeker et al. (2003) interpreted this fact as an increased bone loss due to local disability in relation to the joint affected by osteoarthritis. But in some of these studies (Iwamoto et al., 2002; Hochberg et al., 2004; Schneider et al., 2002), sites of bone mineral density measurements were 
distant from sites of osteoarthritis. It is interesting that the observed inverse relationship between osteoarthritis and low bone density was sometimes restricted to the low or middle grades of osteoarthritis but did not concern the worst grade, i.e., grade 4 of the Kellgren scale (Hannan et al., 1993; Iwamoto et al., 2002). Decrease in physical activity due to symptoms of osteoarthritis could contribute to accelerated bone loss (Yahata et al., 2002). On the other hand, a relation between bone density and occupation, disability or pain was not found in several other studies (Burger et al., 1996; Hannan et al., 1993; Mays, 2001; Nevitt et al., 1995).

Our study failed to show an inverse relationship between osteoarthritis, diagnosed by the presence of osteophytes and bone loss assessed by radiogrammetry. Consequently, the classification of archaeological skeletons into bone losers and bone formers in order to improve the performance of methods assessing age at death was not possible in our study. Since the assessment of adult age at death has been problematic in palaeoanthropology, our negative result remains relevant and such an investigation was worthwhile. Besides, our study confirmed the notion of bone formers. Our sample was composed of individuals from a rather low social class and with similar occupations and life styles. Nevertheless, some of these subjects developed osteophytes whereas others had no joint affected by ageing.

This result deserves further investigation on other samples of known age and sex.

\section{Acknowledgements}

The authors wish to thank the Department of Radiology of Coimbra hospital. We are very grateful to Teresa Rafael and Francisco Curate for their precious help in the taking of radiographs. Financial assistance was provided by a post-doctoral grant from the Fyssen Foundation.

\section{References}

Bateman, J.F., 2005. Genetic aspects of osteoarthritis. Semin. Arthritis Rheum. 34, 15-18.

Bell, L.S., Jones, S., 1991. Macroscopic and microscopic evaluation of archaeological pathological bone: backscattered electron imaging of putative pagetic bone. Int. J. Osteoarchaeol. 1, 179-184.

Belmonte-Serrano, M.A., Bloch, D.A., Lane, N.E., Michel, B.E., Fries, J.F., 1993. The relationship between spinal and peripheral osteoarthritis and bone density measurements. J. Rheumatol. 20, 1005-1013.

Bettica, P., Cline, G., Hart, D.J., Meyer, J., Spector, T.D., 2002. Evidence for increased bone resorption in patients with progressive knee osteoarthritis. Arthritis Rheum. 46, 3178-3184.

Bischoff, H.A., Theiler, R., Lindemann, D., Dick, W., Conzelmann, M., Stähelin, H.B., 2000. No influence of osteoarthritis of the hand on phalangeal osteosonography in elderly women. J. Clin. Densitom. 3, 353-357.

Boldsen, J.L., Milner, G.R., Konigsberg, L., Wood, J.W., 2002. Transition analysis: a new method for estimating age from skeletons. In: Hoppa, R.D., Vanpel, J.W. (Eds.), Paleodemography. Age Distributions from Skeletal Samples. Cambridge University Press, Cambridge, pp. 73-106.

Boonen, S., Nijs, J., Borghs, H., Peeters, H., Vanderschueren, D., Luyten, F.P., 2005. Identifying postmenopausal women with osteoporosis by calcaneal ultrasound, metacarpal digital radiogrammetry and phalangeal radiographic absorbtiometry: a comparative study. Osteoporos. Int. 16, 93-100.

Boyce, T.M., Bloebaum, R.D., 1993. Cortical aging differences and fracture implications for the human femoral neck. Bone 14, 769-778. 
Brickley, M., Waldron, T., 1998. Relationship between bone density and osteoarthritis in a skeletal population from London. Bone 22, 279-283.

Buckberry, J.L., Chamberlain, A.T., 2002. Age estimation from the auricular surface of the ilium: a revised method. Am. J. Phys. Anthropol. 119, 231-239.

Burger, H., Van Daele, P.L., Odding, E., Valkenburg, H.A., Hofman, A., Grobbee, D.E., Schutte, H.E., Birkenhager, J.C., Pols, H.A., 1996. Association of radiographically evident osteoarthritis with higher bone mineral density and increased bone loss with age. The Rotterdam Study. Arthritis Rheum. 39, 81-86.

Cooper, C., Cook, P.L., Osmond, C., Fisher, L., Cawley, M.I.D., 1991. Osteoarthritis of the hip and osteoporosis of the proximal femur. Ann. Rheum. Dis. 50, 540-542.

Cox, M., 2000. Ageing adults from the skeleton. In: Cox, M., May, S. (Eds.), Human Osteology in Archeology and Forensic Science. Greenwich Medical Media, London, pp. 61-81.

Crespo, R., Revilla, M., Usabiago, J., Crespo, E., Garcia-Areno, J., Villa, L.F., Ricon, H., 1998. Metacarpal radiogrammetry by computed radiography in postmenopausal women with Colles's Fracture and vertebral crush fracture syndrome. Calcif. Tissue Int. 62, 470-473.

Crubézy, E., Goulet, J., Bruzek, J., Jelinek, J., Rougé, D., Ludes, B., 2002. Epidémiologie de l'arthrose et des enthésopathies dans une population européenne d'il y a 7700 ans. Revue de Rheumatologie 69 , 1217-1225.

Currey, J.D., 1969. The mechanical consequences of variation in the mineral content of bone. J. Biomech. $2,1-11$.

Del Puente, A., Esposito, A., Carpinelli, A., Nutile, G., Scognamiglio, A., Savastano, S., Postiglione, L., Padula, S., Oriente, P., 2003. Longitudinal study on osteoarthritis and bone metabolism. Reumatismo $55,102-107$.

Dequeker, J., 1997. The inverse relationship between osteoporosis and osteoarthritis. Adv. Exp. Med. Biol. 455, 419-422.

Dequeker, J., Aerssens, J., Luyten, F.P., 2003. Osteoarthritis and osteoporosis: clinical and research evidence of inverse relationship. Aging Clin. Exp. Res. 15, 426-439.

Drees, P., Decking, J., Ghezel-Ahmadi, V., Delank, K.S., Wilhelm, B., Eckardt, A., 2005a. The common occurrence of osteoarthritis and osteoporosis and the value of markers of bone turnover. Z. Rheumatol. 64, 488-498.

Drees, P., Decking, J., Breijawi, N., Delank, S., Kreitner, K.F., Eckardt, A., 2005b. Osteoporosis and osteoarthritis-is there really an inverse relation? Z. Orthop. Ihre. Grenzgeb. 143, 161-169.

El Miedany, Y.M., Mehanna, A.N., El Baddini, M.A., 2000. Altered bone mineral metabolism in patients with osteoarthritis. Joint Bone Spine 67, 521-527.

Falch, J.A., Sandvik, L., 1990. Perimenopausal appendicular bone loss: a 10-year prospective study. Bone 11, 425-428.

Falchetti, A., 2002. Genetics of osteoarticular disorders. Arthritis Res. 4, 326-331.

Geusens, P., Dequeker, J., Verstraeten, A., Nijs, J., 1986. Age-, sex-, and menopause-related changes of vertebral and peripheral bone: population study using dual and single photon absorptiometry and radiogrammetry. J. Nucl. Med. 27, 1540-1549.

Greenfield, E., Goldberg, V., 1997. Genetic determination of bone density. Lancet 350, 1263-1264.

Haara, M., Heliövaara, M., Impivaara, O., Arokoski, JPA., Manninen, P., Knekt, P., Kärkkäinen, A., Reunanen, A., Aromaa, A., Kröger, H., 2006. Low metacarpal index predicts hip fracture. Acta Orthop. 77, 9-14.

Halloran, B.P., Bikle, D.D., 1999. Age-related changesin mineral metabolism. In: Orwoll, E.S. (Ed.), Osteoporosis in Men. Academic Press, London, pp. 179-195.

Hannan, M.T., Anderson, J.J., Zhang, Y., Levy, D., Felson, D.T., 1993. Bone mineral density and knee osteoarthritis in elderly men and women. The Framingham study. Arthritis Rheum. 36, 1671-1680.

Harper, G.J., Crews, D.E., 2000. Aging, senescence, and human variation. In: Stinson, S., Bogin, B., HussAshmore, R., O’Rourke, D. (Eds.), Human Biology, An Evolutionary and Biocultural Perspective. Wiley-Liss, New-York, pp. 465-505.

Hochberg, M.C., Lethbridge-Cejku, M., Plato, C.C., Wigley, F.M., Tobin, J.D., 1991. Factors associated with osteoarthritis of the hand in males: data from the Baltimore longitudinal study of aging. Am. J. Epidemiol. 134, 1121-1127.

Hochberg, M.C., Lethbridge-Cejku, M., Scott Jr., W.W., Plato, C.C., Tobin, J.D., 1994. Appendicular bone mass and osteoarthritis of the hands in women: data from the Baltimore longitudinal study of aging. J. Rheumatol. 21, 1532-1536.

Hochberg, M.C., Lethbridge-Cejku, M., Scott Jr., W.W., Reichle, R., Plato, C.C., Tobin, J.D., 1995. Upper extremity bone mass and osteoarthritis of the knees: data from the Baltimore Longitudinal Study of Aging. J. Bone Miner. Res. 10, 432-438. 
Hochberg, M.C., Lethbridge-Cejku, M., Tobin, J.D., 2004. Bone mineral density and osteoarthritis: data from the Baltimore longitudinal study of aging. Osteoarthr. Cartil. 12 (suppl. A), S45-S48.

Hulet, C., Sabatier, J.P., Souquet, D., Locker, B., Marcelli, C., Vielpeau, C., 2002. Distribution of bone mineral density at the proximal tibia in knee osteoarthritis. Calcif. Tissue Int. 7, 315-322.

Igarashi, Y., Uesu, K., Wakebe, T., Kanazawa, E., 2005. A new method for the estimation of adult skeletal age of death from the morphology of the auricular surface of the ilium. Am. J. Phys. Anthropol. 128, 324-339.

Ives, R., Brickley, M.B., 2004. A procedural guide to metacarpal radiogrammetry in Archaeology. Int. J. Osteoarchaeol. 14, 7-17.

Iwamoto, J., Takeda, T., Ichimura, S., 2002. Forearm bone mineral density in postmenopausal women with osteoarthritis of the knee. J. Orthop. Sci. 7, 19-25.

Jones, G., Nguyen, T., Sambrook, P.N., Kelly, P.J., Eisman, J.A., 1995. A longitudinal study of the effect of spinal degenerative disease on bone density in the elderly. J. Rheumatol. 22, 932-936.

Kalichman, L., Cohen, Z.V.I., Kobyliansky, E., Livshits, G., 2002. Interrelationship between bone aging traits and basic anthropometric characteristics. Am. J. Phys. Anthropol. 14, 380-390.

Kalichman, L., Malkin, I., Kobyliansky, E., 2005. Association between physique characteristics and hand skeletal aging status. Am. J. Phys. Anthropol. 128, 889-895.

Kellgren, J.H., Lawrence, J.S., 1957. Radiological assessment of osteoarthritis. Ann. Rheum. Dis. 16, 494-501.

Livshits, G., 2005. Genetic epidemilology of skeletal system aging in apparently healthy human population. Mech. Ageing Dev. 126, 269-279.

Loughlin, J., 2005. The genetic epidemiology of human primary osteoarthritis: current status. Expert Rev. Mol. Med. 7, 1-12.

Lovejoy, C.O., Meindl, R.S., Prysbeck, T.R., Mensforth, R.P., 1985. Chronological metamorphosis of the auricular surface of the ilium: a new method for the determination of adult skeletal age at death. Am. J. Phys. Anthropol. 68, 15-28.

Maggio, D., Pacifici, R., Cherubini, G., Simonelli, G., Luchetti, M., Aisa, M.C., Cucinotta, D., Adami, S., Senin, U., 1997. Age-related cortical bone loss at the metacarpal. Calcif. Tissue Int. 60, 94-97.

Marcelli, C., Favier, F., Kotzki, P.O., Ferrazzi, V., Picot, M.C., Simon, L., 1995. The relationship between osteoarthritis of the hands, bone mineral density and osteoporotic fractures in elderly women. Osteoporos. Int. 5, 382-388.

Mays, S., 1996. Age-dependent cortical bone loss in a medieval population. Int. J. Osteoarchaeol. 6, 144-154.

Mays, S., 2000. Age-dependant cortical bone loss in women from the 18th and early 19th century. Am. J. Phys. Anthropol. 112, 349-361.

Mays, S., 2001. Effects of age and occupation on cortical bone in a group of 18th-19th century British men. Am. J. Phys. Anthropol. 116, 34-44.

Mays, S., 2006. Age related cortical bone loss in women from a 3rd-4th century AD population from England. Am. J. Phys. Anthropol. 129, 518-528.

Mays, S., Lees, B., Stevenson, J.C., 1998. Age dependent bone loss in the femur in a medieval population. Int. J. Osteoarchaeol. 8, 97-106.

McCullagh, P., Nelder, J.A., 1989. Generalized Linear Models. Chapman \& Hall, London.

Montalban Sanchez, J., Rico Lenza, H., Cortes Prieto, J., Pedrera Zamorano, J.D., 2001. Cortical bone mass and risk factors for osteoporosis among postmenopausal women in our environment. Rev. Clin. Esp. 201, 16-20.

Naganathan, V., Zochling, J., March, L., Sambrook, P.N., 2002. Peak bone mass is increased in the hip in daughters of women with osteoarthritis. Bone 30, 287-292.

Nevitt, M.C., Lane, N.E., Scott, J.C., Hochberg, M.C., Pressman, A.R., Genan, H.K., Cummings, S.R., 1995. Radiographic osteoarthritis of the hip and bone mineral density. Arthritis Rheum. 38, 907-916.

Nordin, B.E.C., Polley, K.J., 1987. Metabolic consequences of the menopause. Calcif. Tissue Int. 41 (suppl. 1), 1-59.

Nuti, R., Martini, G., 1993. Effects of age and menopause on bone density of entire skeleton in healthy and osteoporotic women. Osteoporos. Int. 3, 59-65.

Ohtsuka, M., Michaeli, D., Wasnich, R.D., 2002. Relationship between phalangeal bone density and risk of vertebral fracture. J. Clin. Densitom. 5, 11-15.

Ortner, D.J., 2003. Identification of Pathological Conditions in human Skeletal Remains. Academic Press, London.

Peterlik, M., 1997. Aging, neuroendocrine function, and osteoporosis. Exp. Gerontol. 32, 577-586.

Ralston, S.H., 2005. Genetic determinants of osteoporosis. Curr. Opin. Rheumatol. 17, 475-479. 
Resnick, D., Niwayama, G., 1988. Diagnosis of Bone and Joint Disorders. Saunders, Philadelphia.

Rocha, M.A., 1995. Les collections ostéologiques humaines identifiées du Musée Anthropologique de l'Université de Coimbra. Antropologia Portuguesa 13, 7-38.

Rogers, J., Waldron, T., 1995. A Field Guide to Joint Disease in Archeology. Wiley, Chichester.

Sandini, L., Arokoski, J.P., Jurvelin, J.S., Kroger, H., 2005. Increased bone mineral content but not bone mineral density in the hip in surgically treated knee and hip osteoarthritis. J. Rheumatol. 32, 1951-1957.

Scheffé, H., 1959. The Analyse of Variance. Wiley, New York.

Schmitt, A., 2002. Estimation de l'âge au décès des adultes: des raisons d'espérer. Bull. Mém. Soc. Anthropol. Paris, n.s. 14, 51-73.

Schmitt, A., 2005. Une nouvelle méthode pour estimer l'âge all décès des adultes à partir de la surface sacro-pelvienne iliaque. Bull. Mém. Soc. Anthropol. Paris, n.s., 17, 89-101.

Schneider, D.L., Barrett-Connor, E., Morton, D.J., Weisman, M., 2002. Bone mineral density and clinical hand osteoarthritis in elderly men and women: the Rancho Study. J. Rheumatol. 29, 1467-1472.

Seeman, E., 2003. Physiology of aging. Invited review: pathogenesis of osteoporosis. J. Appl. Physiol. 95, $2142-2151$.

Seeman, E., 2004. The growth and age-related origins of bone fragility in men. Calcif. Tissue Int. 75, 100-109.

Solomon, L., 2001. Clinical features of osteoarthritis. In: Ruddy, S., Harris, Jr., E., Sledge, C. (Eds.), Kelley's Textbook of Rheumatology. Saunders, Philadelphia, pp. 1409-1418.

Sowers, M., 2001. Epidemiology of risk factors for osteoarthritis: systemic factors. Curr. Opin. Rheumatol. 13, 447-451.

Sowers, M., Lachance, L., Jamadar, D., Hochberg, M.C., Hollis, B., Crutchfield, M., Jannausch, M.L., 1999. The associations of bone mineral density and bone turnover markers with osteoarthritis of the hand and knee in pre- and perimenopausal women. Arthritis Rheum. 42, 483-489.

Sowers, M.F., Zobel, D., Weissfield, L., Hawthorne, V.L., Carman, W., 1991. Progression of osteoarthritis of the hand and metacarpal bone loss: a twenty-year followup of incident cases. Arthritis Rheum. 34, 36-42.

Spector, T.D., MacGregor, A.J., 2004. Risk factors for osteoarthritis: genetics. Osteoarthr. Cartilage 12 (suppl. A), S39-S44.

Yahata, Y., Aoyagi, K., Yoshida, S., Ross, P.D., Yoshimi, I., Moji, K., Takemoto, T., 2002. Appendicular bone mass and knee and hand osteoarthritis in japanese women: a cross-sectional study. BMC Musculoskelet. Disord. 3, 24-34. 